\title{
In vitro assessment of the cytotoxic effects of secondary metabolites from Spirulina platensis on hepatocellular carcinoma
}

\author{
Mahboobeh Akbarizare, Hamideh Ofoghi* ${ }^{*}$, Mahnaz Hadizadeh and Nasrin Moazami
}

\begin{abstract}
Background: Spirulina platensis, an edible cyanobacterium, is considered as a valuable and natural resource of novel anticancer agents. This study aimed to investigate the anticancer potential of major bioactive metabolites from Spirulina platensis on hepatocellular carcinoma cells. The total phenolic and alkaloid content of S. platensis were determined using spectrophotometric procedures and thin-layer chromatography. Cellular viability of HepG2 cancer cells and normal fibroblasts was evaluated using MTT assay after $24 \mathrm{~h}$ treatment with $0.02-2 \mathrm{mg} / \mathrm{ml}$ of alkaloids, phenolic compounds, aqueous, and methanol extracts from Spirulina platensis.

Results: Total phenolic and total alkaloid compounds were $150.5 \pm 1.18 \mathrm{mg}$ gallic acid equivalents/mg extract and $11.4 \pm 0.05 \mathrm{mg}$ atropine equivalents/mg extract, respectively. All tested extracts and compounds demonstrated the inhibitory effect on the viability of HepG2 cells in a dose-dependent manner without cytotoxicity on normal cells. The most potent anticancer activity was induced by alkaloids $(2 \pm 0.001 \mathrm{mg} / \mathrm{ml})$ with $80 \%$ reduction in cell viability and an $I_{50}$ of $0.53 \pm 0.08 \mathrm{mg} / \mathrm{ml}$. IC $C_{50}$ values of the aqueous extract, the methanolic extract, and phenolic compounds were $1.7 \pm 0.14,1.28 \pm 0.22$, and $0.86 \pm 0.14 \mathrm{mg} / \mathrm{ml}$, respectively.
\end{abstract}

Conclusions: This is the first report to demonstrate anticancer effects of alkaloids and phenolic compounds of Spirulina platensis in relation to liver cancer.

Keywords: Hepatocellular carcinoma, Cyanobacterium, Spirulina platensis, Alkaloid, Phenolic compounds, Anticancer

\section{Background}

Hepatocellular carcinoma (HCC) that is considered as the most frequent type of liver cancer is the sixth most common neoplasm in the world, and its incidence continues to rise annually [1]. It is a type of tumor with a poor prognosis and highly resistant to chemotherapeutic agents. Therapeutic options for the treatment of patients with early stage of HCC include surgical resection and transplantation which can improve the 5-year survival rate by $25 \%$ [2, 3]. Unfortunately, in most cases, HCC is diagnosed at an advanced stage. Sorafenib, an inhibitor kinase for systemic chemotherapy, is the only approved treatment that increases survival in patients with advanced stage HCC. However, sorafenib is very expensive and has some significant side effects including hemorrhagic

\footnotetext{
* Correspondence: ofoghi@irost.ir

Department of Biotechnology, Iranian Research Organization for Science and Technology (IROST), Tehran, Iran
}

\section{Springer Open}

complications and thromboembolic and cardiac ischemic events [4]. Therefore, there is a need for searching new efficient agents for the treatment of HCC with low toxicity and side effects. Bioactive compounds from natural sources have received increasing attention due to their broad spectrum of therapeutic properties with minimal side effects [5]. Marine microorganisms have been reported as new sources of a huge number of bioactive compounds with interesting pharmaceutical activities [6]. Among the marine microorganisms, cyanobacteria as an exceptional rich source of bioactive compounds are an interesting target for future researches [7]; these Gram-negative photosynthetic prokaryotes produce bioactive secondary metabolites as quorum sensing inhibitory compounds and also as a chemical defense against invading pathogens. Recently, the role of some of these secondary metabolites in killing cancer cells or as antimicrobial, anti-inflammatory, and antiviral agents has been also proved $[8,9]$. 


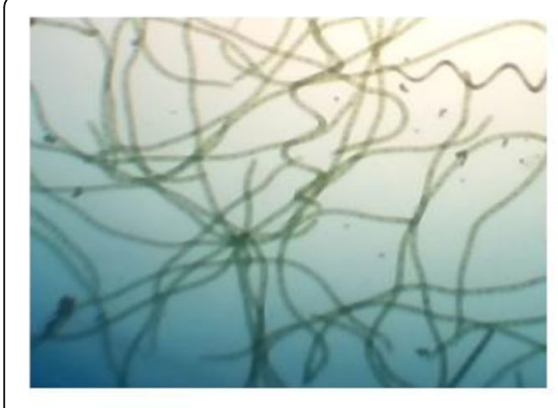

$\mathbf{a}$

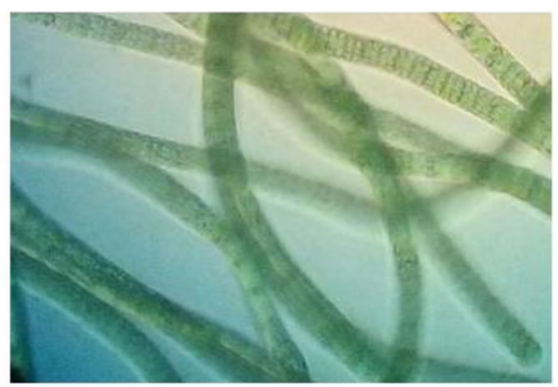

b

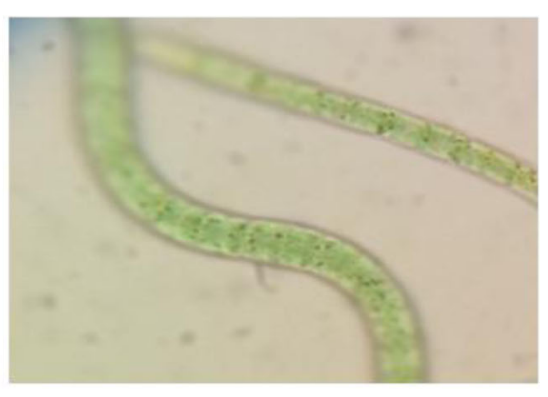

C

Fig. 1 Light microscopic observation of Spirulina platensis. a Magnification $\times 10$. b Magnification $\times 40$. c Magnification $\times 100$

Spirulina platensis (S. platensis), a well-known cyanobacterium with a long history of safe human food consumption, is a multicellular filamentous, spiral-shaped (Fig. 1), and photosynthetic microorganism that can easily grow in fresh water, marshes, and seawater [10]. It contains diverse nutrients such as protein, polyunsaturated fatty acids, vitamins ( $\mathrm{A}, \mathrm{E}$, and $\left.\mathrm{B}_{12}\right)$, minerals, and various pigments. In addition to nutritional value, its potential therapeutic has been also reported [11].

Several studies illustrated that Spirulina extracts can stimulate the immune system, improve glucose and lipid metabolism, and prevent or inhibit different types of cancer [12-15]. Spirulina has also been claimed to prevent chronic diffusion of liver disease [16]. However, there is little information about the effect of secondary metabolites isolated from this cyanobacterium on human tumor cells, and to data, no studies of alkaloids and phenolic compounds extracted from S. platensis were reported on human liver cancer. Although structures of these secondary bioactive metabolites and their pharmacological activities have been determined in plants, there are few studies in cyanobacteria such as Spirulina [17, 18]. Therefore, the aim of this study was to determine the total alkaloid and phenol content and cytotoxic effects of the aqueous and methanolic extracts, and the bioactive compounds which are isolated from S. platensis on the growth of human liver cancer cell line HepG2 as a model of the hepatocellular carcinoma.

\section{Methods}

\section{Materials}

Each constituent of Zarrouk's medium was obtained from Merck. Folin-Ciocalteu reagent, MTT (3-4,5-dimethylthiazol-z-yl)-2,5-diphenyltetrazolium bromide), gallic acid, bromocresol green, and all other chemicals and organic solvents were purchased from Sigma Chemical. Co. Fetal bovine serum (FBS) and other cultural materials were obtained from Invitrogen Corporation (USA). All other chemicals and reagents used in this study were of analytical grade.

\section{Microorganism and growth conditions}

The cyanobacterium S. platensis utilized in this work was obtained from Dr. M. Amin Hejazi (Agricultural Biotechnology Research Institute of Iran) and was grown in Zarrouk's medium [19], under the condition of $\mathrm{pH} 10$ and $30 \pm 2{ }^{\circ} \mathrm{C}$ under the illumination of $4 \mathrm{klx}$ light intensity for 15 days. The harvested biomass was dried in a freeze dryer and stored at $4{ }^{\circ} \mathrm{C}$.

\section{Extract preparation}

To obtain the aqueous extract, the biomass of S. platensis was ground and dried at $40{ }^{\circ} \mathrm{C}$. One gram of dried powder was mixed with $10 \mathrm{ml}$ distilled water and stirred for $60 \mathrm{~min}$. The extract was then centrifuged at 7000 rpm for $20 \mathrm{~min}$. Then the supernatant was separated and dried.

To obtain the methanolic extract, $10 \mathrm{~g}$ of dried powder from S. platensis was extracted with $90 \%$ methanol three times. After filtration, the extract was evaporated at $40{ }^{\circ} \mathrm{C}$ to dryness.

Finally, both the extracts (aqueous and methanol) were dissolved separately in DMSO and diluted with culture medium for the cytotoxicity tests.

\section{Isolation of alkaloids}

Ten grams of ground S. platensis biomass was extracted with methanol. The methanolic extract then was filtrated, and the solvent was evaporated at $40^{\circ} \mathrm{C}$. The crude extract was then extracted with $5 \%$ aqueous acetic acid and filtrated. The filtrate was extracted with $\mathrm{CH}_{2} \mathrm{CL}_{2}$, and the aqueous phase was then basified to $\mathrm{pH} 10$ with $10 \% \mathrm{Na}_{2} \mathrm{CO}_{3}$. The crude alkaloid mixture was then separated from other materials by extraction with $\mathrm{CH}_{2} \mathrm{CL}_{2}$ and the organic solvent evaporation.

\section{Isolation of phenolic compounds}

To isolate phenolic compounds from S. platensis, $0.1 \mathrm{~g}$ of the biomass was dissolved in $10 \mathrm{ml}$ of distilled water and incubated in shaking water bath at $80^{\circ} \mathrm{C}$ for $10 \mathrm{~min}$. Next, the extract was cooled to room temperature and 
centrifuge (6000 rpm, $5 \mathrm{~min})$. The resulting supernatant was then separated and dried. Different concentration of the isolated phenolic compounds was prepared with sterile distilled water and used for testing the cytotoxicity activity.

\section{Determination of total alkaloid content}

Total alkaloid content was determined using back titration method. One gram of the extract was dissolved in chloroform $(25 \mathrm{ml}) ; 25 \mathrm{ml}$ of $\mathrm{H}_{2} \mathrm{SO}_{4}(0.02 \mathrm{~N})$ was then added, and the solution was warmed for the removal of chloroform. Thereafter, the solution was cooled, and excess acid was back titrated with $\mathrm{NaOH}(0.02 \mathrm{~N})$ and methyl red as an indicator. Each milliliter of sulfuric acid was considered to be $5.8 \mathrm{mg}$ of alkaloids [20].

\section{Determination of total phenolic content}

Total phenolic content of the S. platensis extracts was determined by the Folin-Ciocalteu method using the gallic acid as a standard $(10-100 \mu \mathrm{g} / \mathrm{ml})$. Briefly, $1 \mathrm{ml}$ of the extract was diluted 1:10 with distilled water and mixture was incubated with $1 \mathrm{ml}$ of the Folin-Ciocalteu phenol reagent for $5 \mathrm{~min}$ at room temperature. Then, 10 $\mathrm{ml}$ of $7 \% \mathrm{Na}_{2} \mathrm{Co}_{3}$ solution was added to the mixture and adjusted with distilled water to a final volume of $25 \mathrm{ml}$. The absorbance of the reaction was determined at 720 $\mathrm{nm}$. The total phenol content was calculated from the gallic standard curve [21].

\section{Thin-layer chromatography}

The presence of alkaloids and phenolic compounds of $S$. platensis was qualitatively performed by thin-layer chromatography (TLC). Methanolic extracts of S. platensis were spotted on pre-coated silica gel 60 F264 plates. Solvent systems used for the separation of alkaloids and phenols were a mixture of methanol:demineralized water: ethyl acetate (16.5:13.5:100) and chloroform:methanol (27: 0.3). After separation of bioactive compounds, Dragendorff and Folin-Ciocalteu reagents were used respectively to identify the alkaloids and phenolic compounds.

\section{Cell culture}

Liver cancer cell line HepG2 and normal human fibroblast cells were obtained from the National center for sciences, Pasteur Institute, Tehran, Iran. The cells were cultured in RPMI-1640 medium containing 10\% FBS, $100 \mathrm{~V} / \mathrm{ml}$ of penicillin, and $100 \mu \mathrm{g} / \mathrm{ml}$ of streptomycin at $37{ }^{\circ} \mathrm{C}$ in a humidified $5 \% \mathrm{CO}_{2}$ incubator. After $90 \%$ confluency, cells were treated with $0.25 \%$ sterile trypsin and seeded at a concentration of $1.0 \times 10^{4}$ cells/well into 96well microplates for $24 \mathrm{~h}$ prior to the addition of test compounds.

\section{In vitro evaluation of cellular viability}

Liver cancer HepG2 and fibroblast normal cells were plated at a density of $1.0 \times 10^{4}$ cells/well into a flat bottom 96-well plate and incubated at $37^{\circ} \mathrm{C}$ in a humidified $5 \% \mathrm{CO}_{2}$ incubator. On the second day, cells were exposed to various concentrations $(0.02-2 \mathrm{mg} / \mathrm{ml})$ of the aqueous and methanol extracts or the bioactive compounds (phenolic compounds and alkaloids) extracted from S. platensis. The well-containing cells treated with DMSO $(0.5 \%)$ instead of a test compound were utilized as controls. After $24 \mathrm{~h}$ of test compound treatment, $10 \mu \mathrm{l}$ of the MTT solution $(0.5 \mathrm{mg} / \mathrm{ml})$ was added to the wells and plates were incubated for $4 \mathrm{~h}$ at $37^{\circ} \mathrm{C}$. The supernatant was then removed and the violet formazan crystals were dissolved with $100 \mu \mathrm{l}$ DMSO, and adsorption at $570 \mathrm{~nm}$ was measured using a microplate ELISA Redder (Biotek). The $\mathrm{IC}_{50}$ values were calculated from the doseresponse inhibition curve.

\section{Evaluation of morphological changes in cells}

The morphology and viability of HepG2 cancer cells and normal fibroblast cells were observed in an inverted microscope (CETi) with magnification $\times 40$ after $24 \mathrm{~h}$ incubation of cells with $0.02-2 \mathrm{mg} / \mathrm{ml}$ of the phenolic compounds, alkaloids, and methanolic extracts from $S$. platensis.

\section{Results}

Total phenol and alkaloid content

The content of total phenolic compounds in S. platensis extract using the Folin-Ciocalteu reagent was estimated as milligram of gallic acid equivalents per gram of dry weight (mg GA/g DW) of S. platensis. The amount of total phenolic compounds extracted from S. platensis was found $150.5 \pm 1.18 \mathrm{mg} \mathrm{GA} / \mathrm{g}$ DW. The equation obtained from the standard curve was $y=0.00017 x+0.0008$.

The alkaloid content was determined in the S. platensis extract and expressed in terms of atropine equivalents as milligram of atropine per gram of dry S. platensis weight (mg GA/g DW).

The standard curve equation was $y=0.0009 x+0.0761$. According to the standard curve equation, the alkaloid content of S. platensis was found to be $11.4 \pm 0.05 \mathrm{mg}$ AT/g DW.

\section{Thin-layer chromatography}

The methanol extracts of $S$. platensis were evaluated for the presence of phenolic compounds and alkaloids using the TLC technique. As shown in Fig. 2, a total of four different bands were recorded for alkaloids with $\mathrm{Rf}$ values of $0.645,0.375,0.16,0.91$, and 0.75 (Fig. 2).

The TLC profile of total phenolic compounds showed more bands (7) than total alkaloids with $\mathrm{Rf}$ values ranging from 0.07 to 0.65 (Fig. 3). 


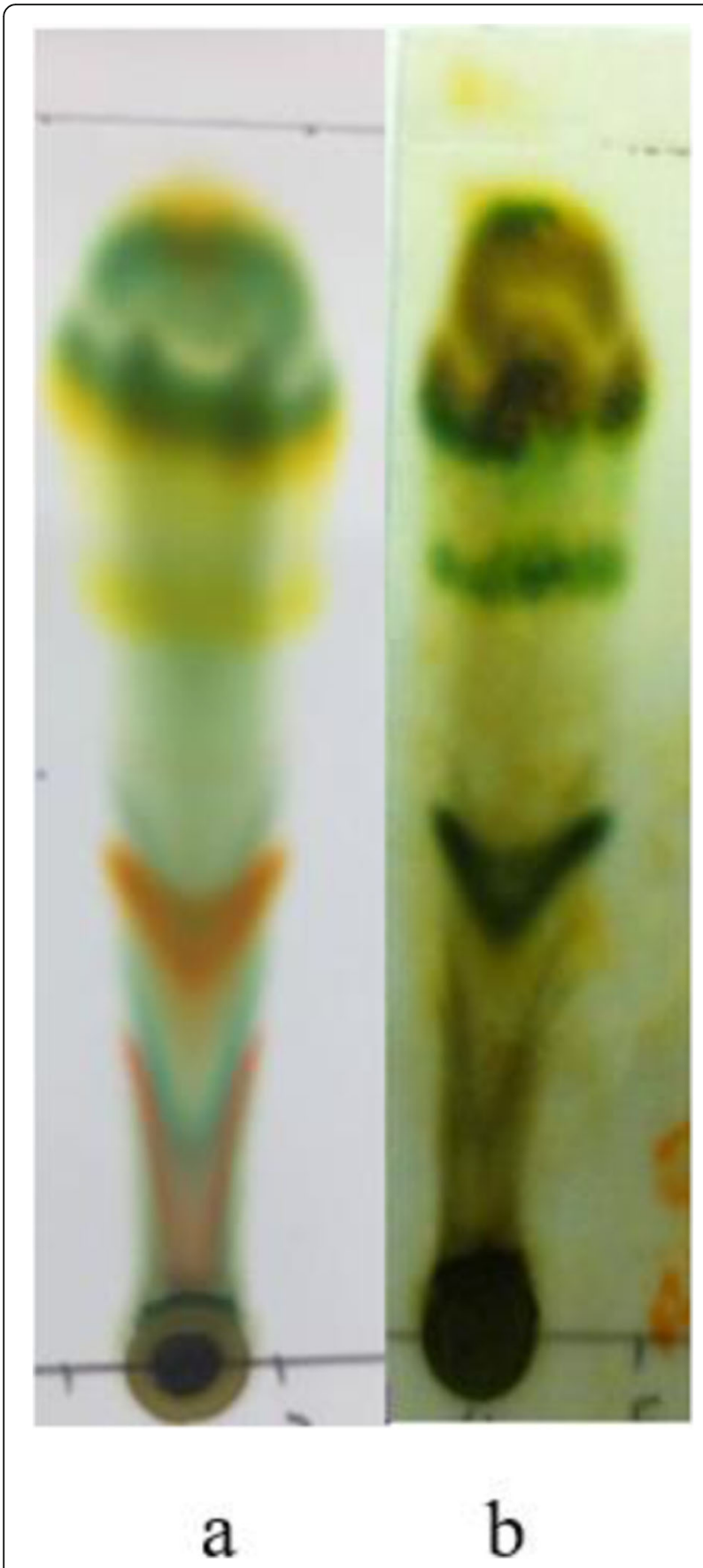

Fig. 2 The profile of alkaloid compounds of S. platensis a with visible light treatment, before sprayed with Dragendorff's reagent $\mathbf{b}$ and after sprayed with Dragendorff's reagent

\section{Evaluation of cellular viability of $S$. platensis extracts and some of its bioactive compounds on HepG2 cells}

The aqueous and methanolic extracts, phenolic compounds, and alkaloids of $S$. platensis were individually assessed for their effects on cell viability of HepG2 cells. All the tested compounds have shown a cytotoxic effect on liver cancer HepG2 cells in a concentration-dependent manner (Fig. 4).

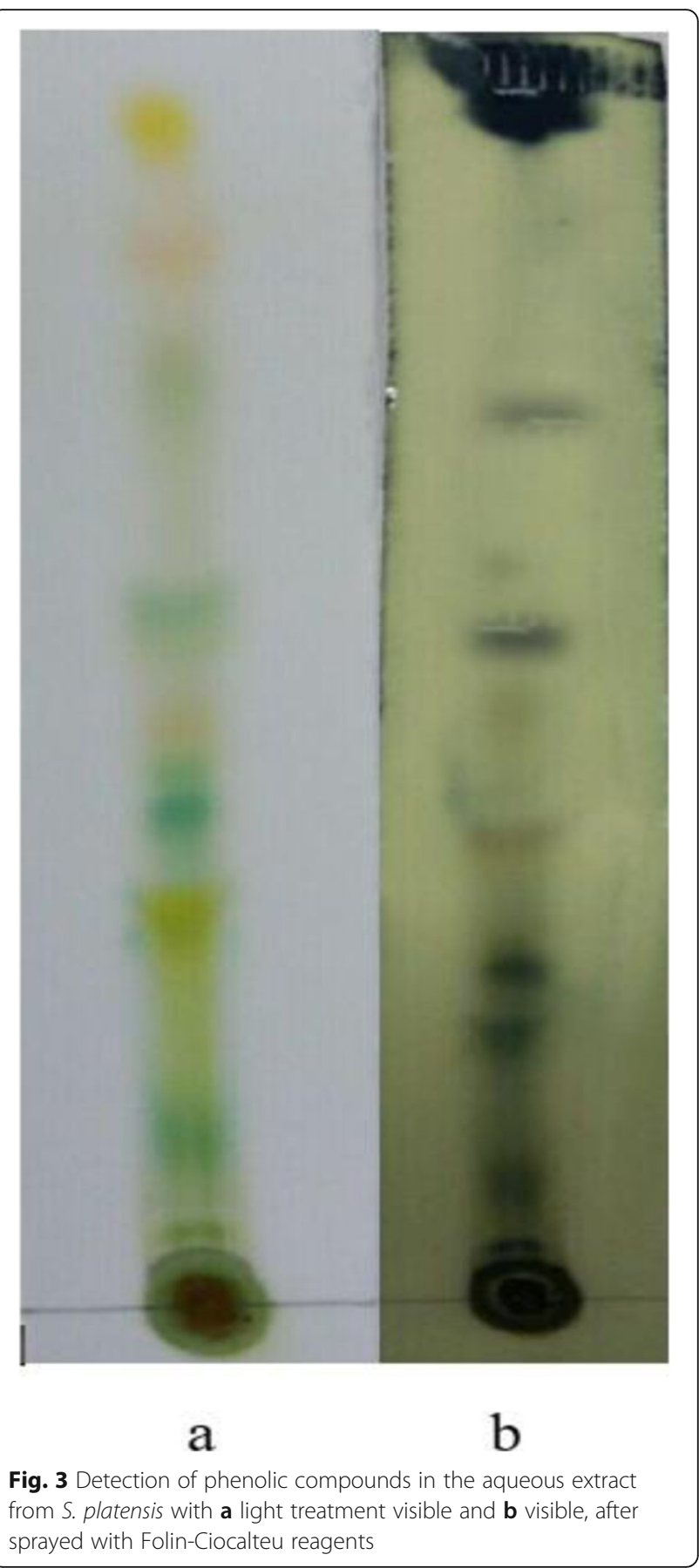

The result also showed that the bioactive compounds extracted from $S$. platensis were more active than crude extracts against HepG2 cells ( 3-fold). The most cytotoxic effect against HepG2 cells was observed with total alkaloids with $\mathrm{IC}_{50}$ value of $0.56 \mathrm{mg} / \mathrm{ml}$. The $\mathrm{IC}_{50}$ values after treatment with aqueous and methanolic extracts and phenolic compounds were $1.9,1.3$, and $0.77 \mathrm{mg} / \mathrm{ml}$ respectively (Table 1 ).

To evaluate the specificity of the tested extracts and compounds to HepG2 cancer cells, the activity of 


\section{HepG2 cell line}

\section{$\mathbf{a}$}

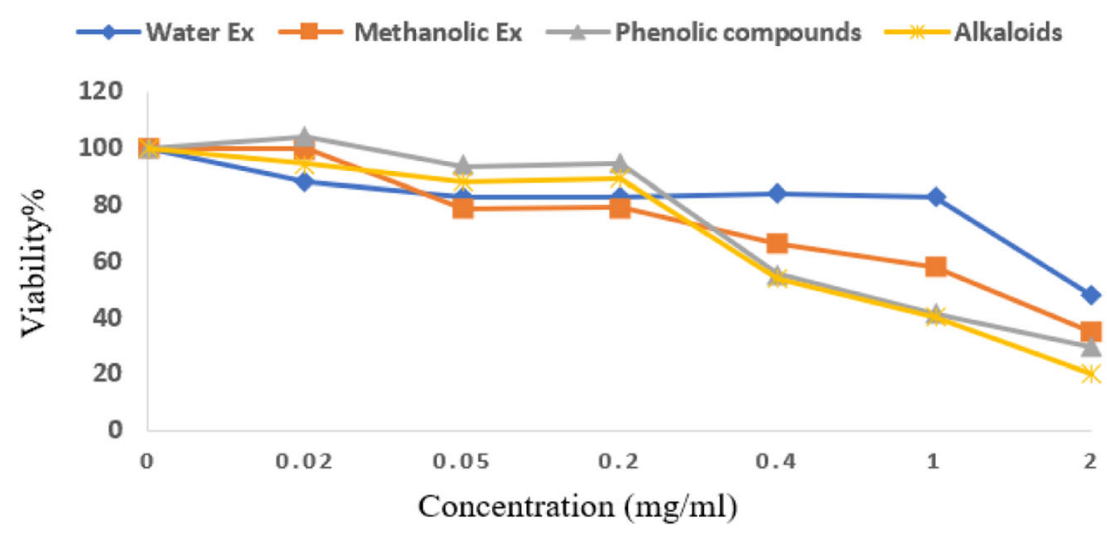

fibroblast cell line

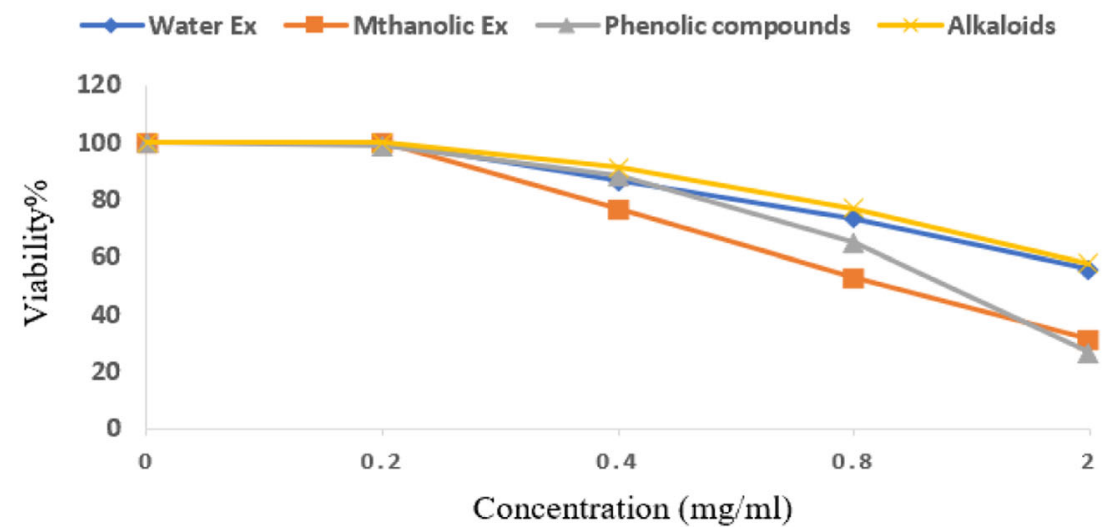

Fig. 4 Evaluation of the cellular viability with different concentrations of phenolic compounds, alkaloids, and aqueous and methanolic extracts of S. platensis on HepG2 cells (a) and fibroblast cells (b) after $24 \mathrm{~h}$ incubation. Values are mean $\pm \mathrm{SD}(n=3)$

these compounds on the viability of normal cells was also examined by cytotoxicity assay using human fibroblast cells. The cells were treated with the same concentration of compounds that were used for HepG2 cancer cells for $24 \mathrm{~h}$. As shown in Fig. 4, all the tested compounds did not affect the viability of normal fibroblast cells with $\mathrm{IC}_{50}>1 \mathrm{mg} / \mathrm{ml}$ and were more specific to cancer HepG2 cells.

Table $1 \mid C_{50}$ values $(\mathrm{mg} / \mathrm{ml})$ obtained for the phenolic compounds, alkaloids, aqueous, and methanolic extracts of $S$. platensis on HepG2 and fibroblast cells

\begin{tabular}{lll}
\hline Bioactive compounds & $\mathrm{HepG}_{2}$ & Fibroblast \\
\hline Aqueous extract & $1.70 \pm 0.14$ & $2.34 \pm 0.06$ \\
Methanolic extract & $1.28 \pm 0.22$ & $2.43 \pm 0.04$ \\
Total phenolic compounds & $0.86 \pm 0.14$ & $1.07 \pm 0.07$ \\
Total alkaloids & $0.53 \pm 0.08$ & $1.46 \pm 0.05$ \\
\hline
\end{tabular}

Microscopic examination of morphological changes in HepG2 cells

After treatment, HepG2 cancer cells and normal fibroblast cells with the phenolic compounds, alkaloids, and aqueous and methanolic extracts from S. platensis, the morphology of HepG2 cells was abnormal compared with untreated cell control, but no significant morphological changes were observed in the normal fibroblast cell (data not shown). All the samples induced severe morphological changes in treated HepG2 cells such as rounding, shrinkage, and floating cells in the medium. It was clear that phenolic compounds and alkaloids had the most cytotoxic effect on HepG2 cells (Fig. 5).

\section{Discussion}

Cyanobacteria are one of the natural sources that demonstrate potential in anti-carcinogenesis. Essentially, the adverse and beneficial effects of extracts from cyanobacteria are due to their phytochemical content. Secondary 


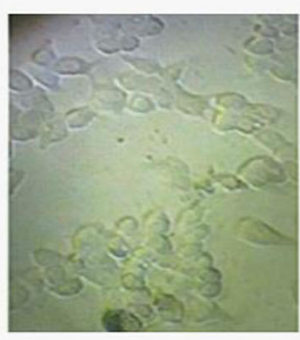

a

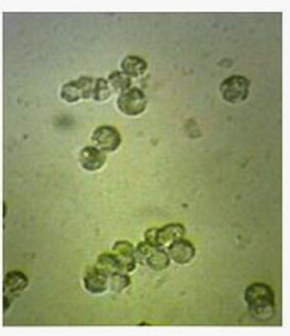

b

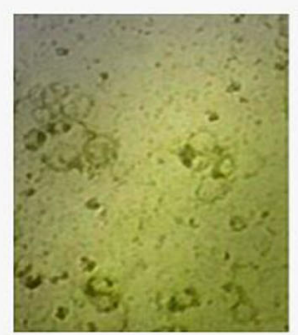

c

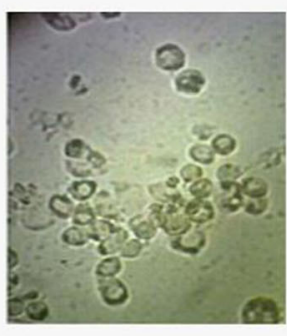

d

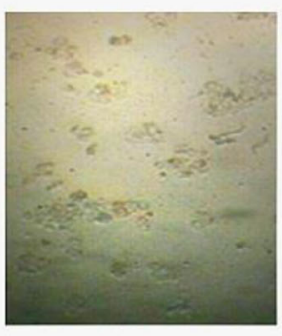

e

Fig. 5 Morphological changes of HepG2 cell line after $24 \mathrm{~h}$ treatment with various extracts and bioactive compounds obtained from S. platensis a control, b $1.8 \mathrm{mg} / \mathrm{ml}$ aqueous extract, c $1.3 \mathrm{mg} / \mathrm{ml}$ methanolic extract, $\mathbf{d} 0.7 \mathrm{mg} / \mathrm{ml}$ phenolic compounds, and e $0.5 \mathrm{mg} / \mathrm{ml}$ alkaloids

metabolites produced by these microorganisms are excellent antioxidant and chemotherapeutic agents which are easily available, safe, and affordable [22].

Among cyanobacteria species, S. platensis is one of the most well-known and popular cyanobacteria due to its valuable constituents and many pharmaceutical activities such as antimicrobial, antioxidant, anti-inflammatory, antiaging, and anticancer activities [23].

The results of this study showed that the aqueous and methanolic extract from S. platensis can inhibit the proliferation of liver cancer cells (HepG2). However, two major secondary metabolites isolated from this cyanobacterium (phenolic and alkaloid compounds) exhibited greater anticancer activity that approximately was 3 -fold and 2.5 -fold more cytotoxic, respectively, than the $S$. platensis extracts. This could be because Spirulina extract is a complex mixture of substances and the part of bioactive compounds may be relatively low. The anticancer capacity of $S$. platensis extracts and some of its bioactive compounds was previously reported for different cell lines including Kasumi-1, K562 [24], pancreatic cancer cells [25], HCT116 colon carcinoma cells [15], Mcf-7 breast cancer cells [26, 27], and HepG2 cells [27]. However, to the best of our knowledge, our study represents the first report on the anticancer activity of alkaloids and phenolic compounds extracted from S. platensis against hepatocellular carcinoma in vitro. Although the mechanism of anticancer activity of these compounds remains to be determined, our studies also indicated that S. platensis extracts and its bioactive compounds in the concentration range used $(0.02-2 \mathrm{mg} / \mathrm{ml})$ only specifically inhibited the growth of liver cancer cells but not significantly affect the proliferation and morphology of normal human fibroblasts. The water and methanolic extracts from Spirulina exhibited dose-dependent cytotoxicity against $\mathrm{HepG} 2$ cells with $\mathrm{IC}_{50}$ of $1.7 \pm 0.14$ and $1.28 \pm 0.22 \mathrm{mg} / \mathrm{ml}$, respectively. Similarly, Wu et al. [28] reported that the water extracts of Spirulina and Chlorella have potent antiproliferative effects on HSC and
HepG2 cells. However, the $\mathrm{IC}_{50}$ values were lower than those reported here. Another study [27] revealed that incubation of breast cancer Mcf-7 and liver cancer $\mathrm{HepG}_{2}$ cells with ethanol and chloroform extracts from S. platensis and Chlorella vulgaris $(100 \mu \mathrm{g} / \mathrm{ml}$ for $24 \mathrm{~h})$ induced some cell inhibition growth, but did not reach $50 \%$ inhibition $\left(\mathrm{IC}_{50}\right)$. The highest concentration of the extracts was $100 \mu \mathrm{g} / \mathrm{ml}$, while we examined the effect of higher concentration of water and methanolic extracts from S. platensis and achieved 50\% inhibition, of HepG2 cell growth after $24 \mathrm{~h}$ treatment. Currently, Hernandez et al. [24] have reported the cytotoxic effects of S. platensis extracts on chronic leukemia K562 and leukemia Kasumi-1 cell line. The $\mathrm{IC}_{50}$ values of Spirulina water extract were found $15.77 \mathrm{mg} / \mathrm{ml}$ and $9.44 \mathrm{mg} / \mathrm{ml}$, respectively, which were higher than those we obtained for HepG2 cells. These differences could be due to constituent variance among Spirulina species, changes in the type and amount of biologically active substances under different growth conditions, and/or type of cells tested. Therefore, in this study, the amounts of two major bioactive metabolites including alkaloids and phenolic compounds isolated from S. platensis were measured. Our results showed that $S$. platensis under the growth conditions listed in the "Methods" section contains 1.14\% and $15.05 \%$ of alkaloids and phenolic compounds, respectively. There are various reports on the content of Spirulina-containing bioactive compound. For example, a study by Agustini et al. [29] indicated the absence of alkaloids in Spirulina, while Ali et al. [30] reported higher phenolic compounds $\left(21.88 \pm 1.67 \mathrm{mg} \mathrm{GAEg}^{-1}\right.$ dry WT) and total alkaloids $(3.02 \pm 0.06 \%)$ than those reported in the present study for S. platensis. Moreover, although in this study, higher total amount and diversity of phenolic compounds isolated from Spirulina were confirmed by the TLC technique compared with its alkaloids, the cytotoxicity studies using these compounds revealed that alkaloids had stronger anticancer activity than the phenolic compounds against hepatoblastoma HepG2 cell. Although, according to 
the literature [31-33], both alkaloids and phenolic compounds isolated from natural sources have shown potent anticarcinogenic activities in vitro and in vivo, based on the results obtained in the present study, we think that molecules with stronger anticancer effects may exist among the alkaloids extracted from S. platensis compared with its phenolic compounds. Therefore, further investigation on alkaloids of S. platensis seems vital. Some of the alkaloids such as camptothecin and vinblastine have already been successfully developed into chemotherapeutic drugs [34]. These secondary metabolites function as therapeutics by modulating key signaling pathways involved in apoptosis, cell cycle, proliferation, and metastasis, as well as inhibiting the enzyme topoisomerases, which disrupts DNA synthesis and DNA repair [35-37]. In summary, this study reports for the first time that alkaloids and phenolic compounds extracted from $S$. platensis cause a dose-dependent inhibition of HepG2 cell growth without significant cytotoxicity in normal human fibroblasts.

Therefore, further studies are needed to isolate, identify, and purify the bioactive molecules present in these compounds. Moreover, research on mechanisms of action will be necessary to better understand the anticancer activity of these bioactive metabolites against hepatocellular carcinoma.

\section{Conclusion}

It can be concluded from the results obtained in this study that alkaloids and phenolic compounds extracted from S. platensis have the potential to further develop as new natural anticancer agents effective against hepatocellular carcinoma, but more confirmatory studies and clinical trials are necessary before the introduction of them for the treatment of $\mathrm{HCC}$.

\section{Acknowledgements}

We gratefully acknowledge Dr. Hejazi (Agricultural Biotechnology Research Institute of Iran) for supplying the strain of Spirulina used in this study.

\section{Authors' contributions}

MA performed experiments and prepared the manuscript; $\mathrm{HO}$ designed and directed the study; $\mathrm{MH}$ co-supervised the study and NM co-advised the study. All authors read and approved the final manuscript.

\section{Funding}

This research did not receive any specific grant from funding agencies in the public, commercial, or not-for-profit sectors.

Availability of data and materials

Data and materials were available for study.

\section{Ethics approval and consent to participate}

Not applicable.

\section{Consent for publication}

Not applicable.

\section{Competing interests}

The authors declare that they have no competing interests.
Received: 29 October 2019 Accepted: 23 January 2020

Published online: 13 March 2020

\section{References}

1. Waghray A, Murali AR, Menon KN (2015) Hepatocellular carcinoma: from diagnosis to treatment. World J Hepatol 7:1020-1029

2. Garrean S, Hering J, Saied A, Helton WS, Espat NJ (2008) Radiofrequency ablation of primary and metastatic liver tumors: a critical review of the literature. Am J Surg 195:508-520

3. Ghouri YA, Mian I, Rowe JH (2017) Review of hepatocellular carcinoma: epidemiology,etiology, and carcinogenesis. J Carcinogenesis 16:1-33

4. Li Y, Gao ZH, Qu XJ (2015) The adverse effects of sorafenib in patients with advanced cancers. Basic Clin Pharmacol Toxicol 116:216-221

5. Caicedo NH, Kumirska J, Neumann J, Stolte S, Thöming J (2012) Detection of bioactive exometabolites produced by the filamentous marine cyanobacterium Geitlerinema sp. Mar Biotechnol 14:436-445

6. Montaser R, Luesch H (2011) Marine natural products: a new wave of drugs? Future Med Chem 3(12):1475-1489

7. Singh R, Parihar $P$, Singh M, Bajguz A, Kumar J, Singh S, Singh VP, Prasad SM (2017) Uncovering potential applications of cyanobacteria and algal metabolites in biology, agriculture and medicine: current status and future prospects. Front Microbiol 8:1-37

8. Mayer AM, Hamann MT (2004) Marine pharmacology in 2000: marine compounds with antibacterial, anticoagulant, antifungal, anti-inflammatory, antimalarial, antiplatelet, anti-tuberculosis, and antiviral activities; affecting the cardiovascular, immune, and nervous systems and other miscellaneous mechanisms of action. Mar Biotechnol 6(1):37-52

9. Vijayakumar S, Menakha M (2015) Pharmaceutical applications of cyanobacteria-a review. J Acute Med 5(1):15-23

10. Saranraj P, Sivasakthi S (2014) Spirulina platensis-food for future: a review. Asian J Pharm Sci Technol 4(1):26-33

11. Khan Z, Bhadouria P, Bisen P (2005) Nutritional and therapeutic potential of Spirulina. Curr Pharm Biotechnol 6(5):373-379

12. Watanuki H, Ota K, Tassakka ACMA, Kato T, Sakai M (2006) Immunostimulant effects of dietary Spirulina platensis on carp, Cyprinus carpio. Aquaculture 258(1-4):157-163

13. Nawrocka D, Kornicka K, Śmieszek A, Marycz K (2017) Spirulina platensis improves mitochondrial function impaired by elevated oxidative stress in adipose-derived mesenchymal stromal cells (ASCs) and intestinal epithelial cells (IECS), and enhances insulin sensitivity in equine metabolic syndrome (EMS) horses. Marine Drugs 15(8):1-27

14. Chu W-L, Lim Y-W, Radhakrishnan AK, Lim P-E (2010) Protective effect of aqueous extract from Spirulina platensis against cell death induced by free radicals. BMC Complement Altern Med 10(1):1-8

15. Zaid AAA, Hammad DM, Sharaf EM (2015) Antioxidant and anticancer activity of Spirulina platensis water extracts. Int J Pharmacol 11(7):846-851

16. Orynchak M, Virstiuk N, Kuprash L, Panteleĭmonova T, Sharabura L (2000) Clinical and experimental study of spirulina efficacy in chronic diffuse liver diseases. Likars' ka sprava 6:89-93

17. Ahuchaogu AA, Chukwu OJ, Echeme JO (2017) Secondary Metabolites from Mimosa Pudica: Isolation, Purification and NMR Characterization. IOSR J Appl Chem 10(3):15-20

18. Kabera JN, Semana E, Mussa AR, He X (2014) Plant secondary metabolites: biosynthesis, classification, function and pharmacological properties. Pharm Pharmacol 2:377-392

19. Zarrouk C. Influence de divers facteuors physiques et chimiques sur lacroissance et la (1966) photosynthese de, Geitle, Spirulina maxima: Ph. D. Thesis, University of Paris, France

20. Shanab SM, Mostafa SS, Shalaby EA, Mahmoud GI (2012) Aqueous extracts of microalgae exhibit antioxidant and anticancer activities. Asian Pac J Trop Biomed 2(8):608-615

21. Yildiz G, Vatan Ö, Celikler S, Dere S (2011) Determination of the phenolic compounds and antioxidative capacity in red algae Gracilaria bursa-pastoris. Int J Food Prop 14(3):496-502

22. Romano G, Costantini M, Sansone C, Lauritano C, Ruocco N, lanora A (2017) Marine microorganisms as a promising and sustainable source of bioactive molecules. Mar Environ Res 128:58-69

23. Hoseini S, Khosravi-Darani K, Mozafari M (2013) Nutritional and medical applications of spirulina microalgae. Mini Rev Med Chem 13(8):1231-1237 
24. Hernandez FYF, Khandual S, López IGR (2017) Cytotoxic effect of Spirulina platensis extracts on human acute leukemia Kasumi-1 and chronic myelogenous leukemia K-562 cell lines. Asian Pac J Trop Biomed 7(1):14-19

25. Konícčková R, Vanňková K, Vaníková J, Vánňová K, Muchová L, Subhanová I, Zadinová M, Zelenka J, Dvorák A, Koláŕ M et al (2014) Anti-cancer effects of blue-green alga Spirulina platensis, a natural source of bilirubin-like tetrapyrrolic compounds. Ann Hepatol 13(2):273-283

26. Chen T, Wong Y-S (2008) In vitro antioxidant and antiproliferative activities of selenium-containing phycocyanin from selenium-enriched Spirulina platensis. J Agric Food Chem 56(12):4352-4358

27. Mohd Syahril M Z, Roshani O, Nur hasyimah R, Mohamad Hafiz M S, Sharida M D, Ahmed H. Y (2011) Screening of anticancer of crude extracts of unicellular green algae (Chlorella vulgaris) and filamentous blue green algae (Spirulina platensis) on selected cancer cell lines. Conference Paper 82-86

28. Wu L-C, Ho J-aA, Shieh M-C, Lu I-W (2005) Antioxidant and antiproliferative activities of Spirulina and Chlorella water extracts. J Agric Food Chem 53(10): 4207-4212

29. Agustini TW, Suzery M, Sutrisnanto D, Ma'ruf WF (2015) Comparative study of bioactive substances extracted from fresh and dried Spirulina sp. Procedia Environ Sci 23:282-289

30. Ali HEA, Shanab SMM, Shalaby EAA, El Demerdash UMN, Abdullah MA (2014) Evaluation of antioxidants, pigments and secondary metabolites contents in Spirulina platensis. Applied Mechanics and Materials; Trans Tech Publ 625: 160-163.

31. Chou S-T, Hsiang C-Y, Lo H-Y, Huang H-F, Lai M-T, Hsieh C-L,Chiang S-Y and Tin-Yun (2017) Exploration of anti-cancer effects and mechanisms of Zuo-JinWan and its alkaloid components in vitro and in orthotopic HepG2 xenograft immunocompetent mice. BMC Complement Altern Med 17(1): 1-11

32. Dai J, Mumper RJ (2010) Plant phenolics: extraction, analysis and their antioxidant and anticancer properties. Molecules 15(10):7313-7352

33. Lu J-J, Bao J-L, Chen X-P, Huang M, Wang Y-T (2012) Alkaloids isolated from natural herbs as the anticancer agents. Evid Based Complement Alternat Med 2012:1-13

34. Lorence A, Nessler CL (2004) Camptothecin, over four decades of surprising findings. Phytochemistry 65(20):2735-2749

35. Habli Z, Toumieh G, Fatfat M, Rahal ON, Gali-Muhtasib H (2017) Emerging cytotoxic alkaloids in the battle against cancer: overview of molecular mechanisms. Molecules 22(2):1-22

36. Mohan V, Agarwal R, Singh RP (2016) A novel alkaloid, evodiamine causes nuclear localization of cytochrome-c and induces apoptosis independent of p53 in human lung cancer cells. Biochem Biophys Res Commun 477(4): 1065-1071

37. Pommier $Y$ (2009) DNA topoisomerase I inhibitors: chemistry, biology, and interfacial inhibition. Chem Rev 109(7):2894-2902

\section{Publisher's Note}

Springer Nature remains neutral with regard to jurisdictional claims in published maps and institutional affiliations.

\section{Submit your manuscript to a SpringerOpen ${ }^{\circ}$ journal and benefit from:}

- Convenient online submission

- Rigorous peer review

- Open access: articles freely available online

- High visibility within the field

- Retaining the copyright to your article

Submit your next manuscript at $\boldsymbol{\nabla}$ springeropen.com 